\title{
Antidiabetic Potential of Stem Bark Extract of Enantia chlorantha and Lack of Modulation of Its Therapeutic Efficacy in Diabetic Rats Co-Administered with Lisinopril
}

\author{
Latifat Bolanle Ibrahim, Patience Funmilayo Idowu, \\ Opemipo Adekanye Moses, Mutiu Adewunmi Alabi ${ }^{\star}$ \\ and Emmanuel Oladipo Ajani
}

\author{
Department of Medical Biochemistry and Pharmacology, Faculty of Pure and Applied Sciences, Kwara State University, \\ Malete, P. M. B. 1530, Ilorin, Nigeria \\ * Corresponding author: E-mail: mutiu.alabi@kwasu.edu.ng \\ Phone: +234-7030428661
}

Received: 08-18-2020

\begin{abstract}
This study validates the antidiabetic efficacy of Enantia chlorantha stem bark and the possible therapeutic implications of the co-administration of lisinopril and E. chlorantha in type 2 diabetic rats. E. chlorantha stem bark was extracted by cold maceration. The inhibitory effect of the plant on carbohydrate metabolizing enzymes and its antioxidative potentials were assessed in vitro. The extract exhibited $\alpha$-amylase and $\alpha$-glucosidase inhibitory activities and also showed antioxidative properties in vitro. Administration of the extract normalized fasting hyperglycemia in vivo by showing $47.24 \%$ reduction in blood glucose levels relative to untreated diabetic rats. Co-administration of E. chlorantha and lisinopril restored serum glucose and serum lipid profile levels. E. chlorantha stem bark displayed antidiabetic potentials as compared with a standard antidiabetic drug (metformin). The study also showed that the plant contained some bioactive compounds which we hypothesize might be responsible for the observed activities. Co-administration of the plant with lisinopril conferred no significant therapeutic advantage on the serum glucose level and lipid profile.
\end{abstract}

Keywords: Antidiabetic; Antioxidants; Co-administration; Enantia chlorantha; Hyperglycemia

\section{Introduction}

Diabetes mellitus is a chronic metabolic disorder that affects the metabolism of carbohydrates, fats and proteins. It is characterized by hyperglycemia which can result from, the pancreas not producing enough insulin or cells of the body not responding properly to the insulin produced. Diabetes mellitus can cause long-term complications such as heart disease, stroke and dysfunction and failure of various organs. ${ }^{1}$ The three main types of diabetes are type 1 , type 2 and gestational diabetes. Both women and men can develop diabetes at any age. Diabetes is associated with major abnormalities in fatty acid metabolism. ${ }^{2}$ The most common lipid pattern in type 2 diabetes consists of hypertriglyceridemia, low High-Density Lipoprotein Cholesterol (HDL-C) and normal plasma levels of Low-Density Lipoprotein Cholesterol (LDL-C). ${ }^{3,4}$ Type 2 diabetes is one of the primary threats to human health due to its increased prevalence and associated complications.

Many and diverse therapeutic strategies for the treatment of type 2 diabetes are known. The conventional treatments for diabetes include the reduction of the body's demand for insulin, stimulation of endogenous insulin secretion, enhancement of the action of insulin at the target tissues and the inhibition of degradation of oligo and disaccharides by enzyme inhibitors. ${ }^{5,6}$ Currently, metformin is considered the initial medication of choice for hyperglycemia in type 2 diabetes due to its effectiveness. Metformin is a biguanide class of antihyperglycemic drug which acts primarily by enhancing the action of insulin in the liver to reduce the rate of hepatic glucose production, to decrease glucose absorption and to increase target cell 
insulin sensitivity. ${ }^{7}$ Improvements in insulin action in skeletal muscle also contribute to the therapeutic actions of metformin, mainly resulting in increased non-oxidative glucose disposal. ${ }^{8}$ Together, these actions reduce blood glucose in the setting of hyperglycemia, with very little potential for inducing hypoglycaemia. ${ }^{9}$ Moreover, the enzymes alpha-glycosidase, is responsible for the breakdown of oligosaccharides, disaccharides and/or polysaccharides to monosaccharides and $\alpha$-amylase degrades starch to more simple sugars (dextrin, maltotriose, maltose and glucose). ${ }^{10}$ The inhibitory action of these enzymes leads to a decrease of blood glucose level, because the monosaccharides are the form of carbohydrates which are absorbed through the mucosal border in the small intestine. However, many of the synthetic hypoglycemic agents have their limitations; are non-specific, produce serious side effects and fail to alleviate diabetic complications. The main side effects of these agents are gastrointestinal i.e. bloating, abdominal discomfort, diarrhea, and flatulence. ${ }^{11}$

There is need to develop effective, safe and cheap drugs for diabetes management because of the side effects associated with the present antidiabetic drugs. Drugs from medicinal plants are effective, safe and cheap for the management of diabetes. Many clinical studies have supported the view that utilization of herbal medicines could be a reliable alternative to manage diabetes effectively with little or no adverse effect. ${ }^{12,13}$

Enantia chlorantha belongs to Annonaceae family. This plant is commonly known as African yellow wood. Among the Yoruba in Nigeria it is known as Awopa. ${ }^{14}$ In traditional medicine, this plant has been used for a long time in many parts of the African continent to treat various ailments of the human body. Many of these uses are supported by several studies. ${ }^{15-18}$ For example, it was reported that a decoction of $500 \mathrm{~g}$ of stem bark in $3 \mathrm{l}$ of water for $20 \mathrm{~min}$ may be used to treat malaria symptoms, aches, wounds, boils, vomiting, yellow fever, chills, sore, spleen in children and hepatitis. ${ }^{15}$

Lisinopril is an oral long-acting angiotensin converting enzyme (ACE) inhibitor. ACE inhibitors (ACE-Is) are a family of drugs commonly prescribed to combat hypertension. The primary vasodilatory action of ACE-Is is the blockage of ACE and thus preventing the formation of angiotensin II. ${ }^{19}$ With long-term administration, ACEIs lower blood pressure, even in patients with low renin hypertension. This thus suggests that effect of lisinopril may be independent of a decrease in angiotensin II. The appropriate blood pressure control in diabetes trial found that diabetic patients treated with ACE-Is had lower incidence of myocardial infarction (MI) and overall cardiac events. ACE-Is have been used for years to reduce the rate of diabetic nephropathy progression in patients with type 2 diabetes. ${ }^{19}$ Thus, this drug may be efficacious in treatment of patients with type 2 diabetes.

Herb-Drug interactions (HDIs) are either pharmacodynamic (PD) or pharmacokinetic (PK) in nature. For the former, this occurs when co-administered substances enhance or negate each other's effects as a result of similar or disparate pharmacological activities, respectively. ${ }^{20}$ Such interactions may render the drug less effective or change its activity and producing adverse effect. PK interactions on the other hand arise from the ability of the substance to modulate the absorption, distribution, metabolism and/or excretion (ADME) of the drug. ${ }^{20}$

Despite the fact that $E$. chlorantha is commonly used among the local communities in Nigeria in the management of diabetes, scientific data in support of this local medicinal use in diabetes is lacking in the literatures. Moreover, whereas, the general practice in the management of diabetes in Nigeria is to combine the use of antidiabetic and antihypertensive agents, no study has reported on the therapeutic implications of combining E. chlorantha with any hypertensive agent. In view of the foregoing, the present study investigates the anti-diabetic properties of E. chlorantha stem bark extract and the thermodynamic implications of its co-administration with lisinopril. In addition, the study investigated the phytochemical constituents of the plant to identify the bioactive components that may be responsible for the pharmacological antidiabetic properties and the possible mechanism for its pharmacological action.

\section{Materials and Methods}

\section{1. Materials}

Streptozocin was a product of Sigma-Aldrich, USA. Metformin (Glucophage $500 \mathrm{mg}$ ) was manufactured by Merck Santé, France and Lisiofil (Lisinopril $5 \mathrm{mg}$ ) was manufactured by Fourrts India Laboratories Pvt Ltd., India. All the reagent kits used for bioassay were sourced from Randox Laboratories Ltd., Crumlin, UK. All other chemicals were of analytical grade.

\section{2. Methods}

\section{2. 1. Plant Collection, Identification and Crude Extract Preparation}

The stem bark of $E$. chlorantha was collected in June 2018. The plant sample was identified and authenticated and a voucher number UIH/001/1356 was assigned. Thereafter, a sample specimen was deposited at the herbarium of the University of Ilorin, Ilorin, Nigeria. The stem bark was cleaned to remove adhering dirt, air-dried for two weeks and ground into powder using an electric blender. Extraction was carried out by cold maceration of $800 \mathrm{~g}$ of the coarse powder with $5 \mathrm{~L}$ of $70 \%$ ethanol for 72 $\mathrm{h}$, with constant shaking. The resultant mixture was filtered using Whatman filter paper (No.1) and the filtrate was concentrated using a rotary evaporator at $40^{\circ} \mathrm{C}$. The extract was weighed, and the final yield was $12.5 \%$. The dried extract was finally reconstituted in distilled water for use in the study. 


\section{2. 2. Qualitative and Quantitative Phytochemical Screening}

Qualitative phytochemical analysis of the extract was carried out using the method previously described ${ }^{21}$ to identify phytochemicals while quantitative phytochemical screening was carried out using different method previously described, for saponins, ${ }^{22}$ tannins, ${ }^{23}$ alkaloids ${ }^{24}$ and flavonoids. ${ }^{25}$

\section{3. Antioxidant Assay}

\section{3. 1. 1,1-Diphenyl-2-picryl-hydrazyl Radical Inhibition}

The method previously described ${ }^{26}$ was used to evaluate the 1,1-diphenyl-2-picryl-hydrazyl (DPPH) radical scavenging potential of the extract. One (1) $\mathrm{ml}$ of different concentrations $(0.2-1.0 \mathrm{mg} / \mathrm{ml})$ of the extract or vitamin C (reference) were added to $1 \mathrm{ml}$ of $0.2 \mathrm{mM}$ methanolic solution of DPPH. Similarly, sterile distilled water $(1 \mathrm{ml})$ was mixed with an aliquot $(1 \mathrm{ml})$ of $0.2 \mathrm{mM}$ methanolic DPPH and used as control. Following incubation $\left(30 \mathrm{~min}, 25^{\circ} \mathrm{C}\right)$ in each case, the absorbance was read against blank at 516 nm using a spectrophotometer (Beckman, DU 7400, USA). The inhibitory effect (I\%) of EOAE on DPPH radical was estimated as follow:

$$
\text { Inhibitory effect }(\mathrm{I} \%)=\frac{\mathrm{A} \text { control }-\mathrm{A} \text { test }}{\mathrm{A} \text { control }} \times 100
$$

where A control is the absorbance of the control and A test is the absorbance of the test sample. Thereafter, the concentration of the extract eliciting $50 \%$ inhibitory $\left(\mathrm{IC}_{50}\right)$ effect on the DPPH radical was calculated from a standard curve.

\section{3. 2. Hydrogen Peroxide Inhibition}

This was estimated using the adapted method previously described. ${ }^{27}$ Briefly $0.6 \mathrm{ml}$ of $40 \mathrm{mM} \mathrm{H}_{2} \mathrm{O}_{2}$ was mixed with $3.4 \mathrm{ml}$ of phosphate-buffered $(\mathrm{pH} 7.4)$ solution $(0.2-$ $1.0 \mathrm{mg} / \mathrm{ml}$ ) concentrations of either the extract or vitamin $\mathrm{C}$ and incubated at $25^{\circ} \mathrm{C}$ for $10 \mathrm{~min}$. Sterile distilled water replaced the extract for the control sample. The absorbance was read spectrophotometrically at $230 \mathrm{~nm}$. The $\mathrm{H}_{2} \mathrm{O}_{2}$ inhibitory potential of the extract was calculated as follow:

$$
\% \mathrm{H}_{2} \mathrm{O}_{2} \text { scavenged }=\frac{\text { A test }- \text { A sample }}{\text { A control }} \times 100
$$

Where, A control is the absorbance of the control; A test and A sample represent the absorbance of the mixture with the extract and that of the extract alone, respectively. The $\mathrm{IC}_{50}$ value was estimated from the standard curve.

\section{3. 3. Hydroxyl Radical $\left(\mathrm{OH}^{-}\right)$Inhibition}

The $\mathrm{OH}^{\circ}$ inhibitory effect of the extract was determined as previously described.$^{28} \mathrm{In}$ brief, $2 \mathrm{ml}$ at $0.2-1.0$ $\mathrm{mg} / \mathrm{ml}$ of the extract or vitamin $\mathrm{C}$ (reference) were mixed with $0.6 \mathrm{ml}$ of ferrous sulfate $(8 \mathrm{mM}), 0.5 \mathrm{ml}$ of $\mathrm{H}_{2} \mathrm{O}_{2}(20$ $\mathrm{mM})$, and $2 \mathrm{ml}$ of salicylic acid $(3 \mathrm{mM})$. After $30 \mathrm{~min}$ of incubation $\left(37^{\circ} \mathrm{C}\right)$, distilled water $(0.9 \mathrm{ml})$ was added and the resulting mixture centrifuged (Beckman and Hirsch, Burlington, IO, USA) at $4472 \mathrm{~g}$ for $10 \mathrm{~min}$. For the control, sterile distilled water was used. The absorbance was read at $510 \mathrm{~nm}$, and the $\mathrm{IC}_{50}$ value was calculated subsequent to determination of inhibitory capacity of the extract against $\mathrm{OH}^{*}$ using the expression:

$$
\begin{aligned}
& \% \text { hydroxyl radical scavenged }= \\
& =\frac{\mathrm{A} \text { test }-\mathrm{A} \text { sample }}{\mathrm{A} \text { control }} \times 100
\end{aligned}
$$

Where, A control, A test, and A sample represent the absorbance of the control, mixture with the extract, and that of the extract alone, respectively.

\section{3. 4. Reducing Power Activity}

The reducing power of extract was determined by previously described method. ${ }^{29}$ One (1) ml of extracts or gallic acid (reference) was mixed with $2.5 \mathrm{ml}$ of phosphate buffer $(200 \mathrm{mM}, \mathrm{pH} 6.6)$ and $2.5 \mathrm{ml}$ of $1 \%$ potassium ferricyanide. The mixtures were incubated for $20 \mathrm{~min}$ at $50^{\circ} \mathrm{C}$. After incubation, $2.5 \mathrm{ml}$ of $10 \%$ trichloroacetic acid were added to the mixtures, followed by centrifugation at 4000 $\mathrm{rpm}$ for $10 \mathrm{~min}$. The upper layer $(5 \mathrm{ml})$ was mixed with 5 $\mathrm{ml}$ of distilled water and $1 \mathrm{ml}$ of $0.1 \%$ ferric chloride and the absorbance of the resultant solution were measured at $700 \mathrm{~nm}$.

\section{4. In vitro Carbohydrate-Metabolizing Enzymes' Inhibitory Assay}

\section{4. 1. Alpha-Amylase Inhibition Assay}

The alpha amylase inhibitory assay was performed as previously described method. ${ }^{30}$ Briefly, concentrations $(50-200 \mathrm{mg} / \mathrm{ml})$ of the extract or acarbose (standard) were prepared and $50 \mu \mathrm{l}$ of the extract or acarbose was added to $500 \mu \mathrm{l}$ of $20 \mathrm{mM}$ sodium phosphate buffer ( $\mathrm{pH}, 6.9$, with 6 $\mathrm{mM} \mathrm{NaCl}$ ) containing porcine pancreatic alpha-amylase $(0.5 \mathrm{mg} / \mathrm{ml})$ and incubated at $25{ }^{\circ} \mathrm{C}$ for $10 \mathrm{~min}$. One unit of the enzyme will liberate $1.0 \mathrm{mg}$ of maltose from starch in $3 \mathrm{~min}$. Then, $500 \mu \mathrm{l}$ of $1 \%$ starch solution in $20 \mathrm{mM}$ sodium phosphate buffer ( $\mathrm{pH} 6.9$, with $6 \mathrm{mM} \mathrm{NaCl}$ ) was added to each tube. The reaction mixture was incubated at $25^{\circ} \mathrm{C}$ for $10 \mathrm{~min}$ and stopped with $1.0 \mathrm{ml}$ of 3,5-dinitrosalicylic acid colour reagent. Thereafter, the mixture was incubated in a boiling water bath for $5 \mathrm{~min}$ and cooled to room temperature. The reaction mixture was then diluted by adding $10 \mathrm{ml}$ of distilled water, and absorbance was measured at $540 \mathrm{~nm}$. The control experiment was performed without the test sample, and the $\alpha$-amylase inhibi- 
tory activity was expressed as percentage inhibition using the following equation:

$$
\% \text { Inhibition }=\frac{\Delta \mathrm{A}_{\text {control }}-\Delta \mathrm{A}_{\text {extract }}}{\Delta \mathrm{A}_{\text {control }}} \times 100
$$

Where $\Delta \mathrm{A}_{\text {extract }}$ and $\Delta \mathrm{A}$ control are the respective changes in absorbance of the extract sample and control. The $\mathrm{IC}_{50}$ of the extract against $\alpha$-amylase activity was thereafter calculated from a standard calibration plot.

\section{4. 2. Alpha-Glucosidase Inhibition Assay}

The assay was performed as previously described. ${ }^{31}$ Briefly, known concentrations $(50-200 \mathrm{mg} / \mathrm{ml}$ ) of the extract or acarbose (standard) were prepared and $50 \mu \mathrm{l}$ of the extract or acarbose was added to $100 \mu \mathrm{l}$ of alpha-glucosidase solution $(1.0 \mathrm{U} / \mathrm{ml})$ in $0.1 \mathrm{M}$ phosphate buffer $(\mathrm{pH}$, 6.9) and incubated at $25^{\circ} \mathrm{C}$ for $10 \mathrm{~min}$. One unit of the enzyme will liberate $1.0 \mu \mathrm{mol}$ of $\mathrm{D}$-glucose from p-nitrophenyl- $\alpha$-D-glucoside per min. Then, $50 \mu \mathrm{l}$ of $5 \mathrm{mM} \mathrm{p}$-nitrophenyl- $\alpha-\mathrm{D}$-glucopyranoside solution in $0.1 \mathrm{M}$ phosphate buffer ( $\mathrm{pH}$ 6.9) was added. The mixture was incubated at $25^{\circ} \mathrm{C}$ for $5 \mathrm{~min}$, and the absorbance was measured at $405 \mathrm{~nm}$. The control experiment was performed without the test sample, and the a-glucosidase inhibitory activity was expressed as percentage inhibition using the following equation:

$$
\% \text { Inhibition }=\frac{\Delta \mathrm{A}_{\text {control }}-\Delta \mathrm{A}_{\text {zxtract }}}{\Delta \mathrm{A}_{\text {control }}} \times 100
$$

Where $\Delta \mathrm{A}_{\text {extract }}$ and $\Delta \mathrm{A}$ control are the respective changes in absorbance of the extract sample and control. The $\mathrm{IC}_{50}$ of the extract against $\alpha$ - glucosidase activity was thereafter calculated from a standard calibration plot.

\section{5. Experimental Protocols}

\section{5. 1. Experimental Animals}

The experiment was carried out on healthy forty-nine (49) male Wistar rats of about 10-12 weeks old and weighing an average of $169 \pm 6 \mathrm{~g}$. The rats were housed in metallic cages at the animal house. The rats were acclimatized for fourteen days and fed with commercial diets and water ad libitum. They were all maintained at $25 \pm 2{ }^{\circ} \mathrm{C}$ light and dark cycle of $12 / 12 \mathrm{hr}$, respectively.

\section{5. 2. Induction of Diabetes}

Type 2 diabetes was induced by the previously described method. ${ }^{32}$ The rats were first fed $15 \%$ fructose solution (w/v) for four weeks, after which they were fasted overnight and thereafter administered streptozotocin (40 $\mathrm{mg} / \mathrm{kg}$ i.p.) freshly prepared in $0.1 \mathrm{M}$ sodium citrate buffer. The diabetic state was confirmed $72 \mathrm{~h}$ after streptozotocin injection. Specifically, rats having fasting blood glucose levels greater than $200 \mathrm{mg} / \mathrm{dl}$ were considered diabetic.

\section{5. 3. Animal Grouping/Administration}

Forty-two (42) diabetic male Wistar rats were divided into six (6) groups consisting of seven (7) rats each: Diabetic groups consisted of DC - Diabetic Control group; treatment groups (T1 - E. chlorantha $(200 \mathrm{mg} / \mathrm{kg}$ b.w.), T2 - Metformin (7.14 mg/kg b.w.), T3 - E. chlorantha + lisinopril (200 mg/kg b.w. and $0.14 \mathrm{mg} / \mathrm{kg}$ b.w. respectively), T4 - Metformin + lisinopril $(7.14 \mathrm{mg} / \mathrm{kg}$ b.w. and $0.14 \mathrm{mg} / \mathrm{kg}$ b.w. respectively) and $\mathrm{T} 5$ - lisinopril $(0.14 \mathrm{mg} / \mathrm{kg}$ b.w.)) and another seven (7) non-diabetic male rats acted as the Normal control group. All administrations were carried out orally as a single dose daily for four weeks using a gavage needle. The rats were housed in cages in the Department Animal Facility Center maintained at $25 \pm 2{ }^{\circ} \mathrm{C}$ light and dark cycles of $12 / 12 \mathrm{hr}$. The chosen dose of the extract and the route of administration were informed by both the results of our ethnobotanical survey on the use of the plant in the management of diabetic and the reported minimum effective (ME) and maximum safe (MS) dose of the plant. $^{33,34}$ The rats were maintained in accordance with the principles of laboratory animal care guidelines. ${ }^{35}$ The weight of the rats was determined every week throughout the experiment period. The experiment was designed according to the Department Animal Ethics Committee guidelines and approval certificate (KSUMB/005/01/013) was given.

\section{5. 4. Monitoring of Blood Glucose Level during Treatment}

All blood samples for monitoring of blood glucose level in situ were taken from the tail vein of the rats using 24 gauge needles at intervals of $0,5,10$, and 15 days. Blood glucose levels were determined by the glucose oxidase method using reactive strips and a single touch glucometer (Accu-Chek Active, Roche Diagnostics, Mannheim, Germany). Results were recorded in $\mathrm{mg} / \mathrm{dl}$. Percentage reduction in fasting blood glucose was calculated as:

$$
\begin{aligned}
& \% \text { Reduction of FBS }= \\
& =\frac{\text { Initial value }- \text { Final value }}{\text { Initial value }} \times 100
\end{aligned}
$$

\section{6. Biochemical Assay}

Twenty-four hours after the last treatment, under mild diethylether anesthesia, the animals were sacrificed, and blood was obtained via jugular puncture and serum was obtained by centrifugation. Isolated serum was analyzed for total cholesterol, HDL- cholesterol (HDL-C), LDL-cholesterol (LDL-C) and total glycerides (TG) colorimetrically using Randox diagnostic kits. 


\section{7. Data Analysis}

All data were presented as mean \pm standard error of mean (S.E.M) of seven replicates. One-way analysis of variance (ANOVA) using SPSS software package for windows (Version 16) for differences between means was used to detect differences between the treatment groups $(\alpha<$ 0.05 ) followed by the Tukey post hoc test using R statistical software.

\section{Results and Discussion}

\section{1. Screening and Detection of Phytoconstituents}

E. chlorantha stem bark gave positive results for some major constituents; alkaloids, saponins, flavonoids, coumarins, anthocyanins and phenolics (Table 1). Terpenes, terpenoids, steroids and glycosides were not detected. The Table also showed that flavonoid concentration was the highest $(114.92 \pm 0.36 \mathrm{mg} / \mathrm{kg})$ while saponin concentration was the lowest $(40.50 \pm 0.71 \mathrm{mg} / \mathrm{kg})$.

\section{2. Antioxidant Assay}

Presented in Table 2 and Table 3 are the results of the in vitro antioxidant assay of the stem bark extract of $E$. chlorantha. The extract showed a significant inhibition of
DPPH radical with an $\mathrm{IC}_{50}$ of $62 \mathrm{mg} / \mathrm{ml}$. The extract also showed a strong scavenging capacity of $\mathrm{H}_{2} \mathrm{O}_{2}$ and $\mathrm{OH}^{*}$. In addition, the extract demonstrated Ferric Reducing Antioxidant Power (FRAP).

Table 2. \% DPPH (2,2-diphenyl-1-picrylhydrazyl) inhibition of $E$. chlorantha extract

\begin{tabular}{ccc}
\hline $\begin{array}{c}\text { Concentration } \\
(\mathbf{m g} / \mathbf{m l})\end{array}$ & $\begin{array}{c}\text { E. Chlorantha } \\
\mathbf{( \% )}\end{array}$ & $\begin{array}{c}\text { Vitamin C } \\
\mathbf{( \% )}\end{array}$ \\
\hline 20 & $31.781 \pm 0.085^{\mathrm{a}}$ & $35.474 \pm 0.969^{\mathrm{a}}$ \\
40 & $61.791 \pm 0.040^{\mathrm{a}}$ & $67.540 \pm 0.085^{\mathrm{a}}$ \\
60 & $62.025 \pm 0.064^{\mathrm{a}}$ & $70.590 \pm 0.180^{\mathrm{a}}$ \\
80 & $69.990 \pm 0.000^{\mathrm{a}}$ & $80.720 \pm 0.270^{\mathrm{b}}$ \\
100 & $79.850 \pm 0.085^{\mathrm{a}}$ & $90.590 \pm 0.200^{\mathrm{b}}$ \\
\hline
\end{tabular}

Data are presented as mean \pm SEM of 3 replicates. Value on the same row with similar superscripts are not significantly $(P>0.05)$ different from each other.

\section{3. Effect of Treatment with E. chlorantha on Blood Glucose and Total Body Weight}

Figure 1 is the result of the effect of treatment on the body weight changes. There was no significant difference in the body weight of all the rats between the groups before treatment. Body weights of rats in diabetic control group were observed to be lower than those in other groups after the treatment period.

Table 1. Qualitative and quantitative phytochemical screening of E. chlorantha

\begin{tabular}{|c|c|c|c|c|}
\hline $\begin{array}{l}\text { Phytochemical } \\
\text { group }\end{array}$ & Reagent used & Observations & Result & $\begin{array}{c}\text { Concentrations } \\
(\mathrm{mg} / \mathrm{kg})\end{array}$ \\
\hline Alkaloids & Wagner's reagent & A reddish-brown precipitate & + & $82.12 \pm 0.02$ \\
\hline Triterpenes & Acetic anhydride & No blue green colour & - & ND \\
\hline Glycosides & Fehling's solution & No brick red precipitate & - & ND \\
\hline Saponins & Frothing test & Frothing precipitate & + & $40.50 \pm 0.71$ \\
\hline Tannins & $\mathrm{KOH}$ & No dirty white precipitate & - & ND \\
\hline Phlobatannin & $\mathrm{HCl}$ & Absence of red precipitate & - & ND \\
\hline Steroids & Salakowsti test & No red colouration & - & ND \\
\hline Flavonoids & Ferric chloride & Yellow colour after $\mathrm{HCl}$ & + & $114.92 \pm 0.36$ \\
\hline Coumarin & & & + & ND \\
\hline Anthocyanins & & & + & ND \\
\hline Terpenoids & Liberman Burchard & No reddish-brown boundary & - & ND \\
\hline Phenolics & $\mathrm{FeCl}_{3}$ & A greenish precipitate & + & ND \\
\hline
\end{tabular}

+ = detected, - = not detected; $\mathrm{ND}=$ not determined

Table 3. Percentage $\mathrm{OH}^{-}, \mathrm{H}_{2} \mathrm{O}_{2}$ and FRAP Scavenging Activity of E. chlorantha Extract

\begin{tabular}{lccc}
\hline \multicolumn{1}{c}{ Agent } & $\mathbf{O H}^{*}(\mathbf{\%})$ & $\mathbf{H}_{\mathbf{2}} \mathbf{O}_{\mathbf{2}}(\mathbf{\%})$ & FRAP (\%) \\
\hline E. chlorantha & $102.650 \pm 0.939^{\mathrm{a}}$ & $42.347 \pm 3.002^{\mathrm{a}}$ & $148.240 \pm 6.912^{\mathrm{a}}$ \\
Reference & $118.727 \pm 0.000^{\mathrm{a}}$ & $67.364 \pm 0.000^{\mathrm{b}}$ & $168.273 \pm 0.000^{\mathrm{a}}$ \\
\hline
\end{tabular}

Data are presented as mean \pm SEM of 3 replicates. Value on the same row with similar superscripts are not significantly $(P>0.05)$ different from each other. 


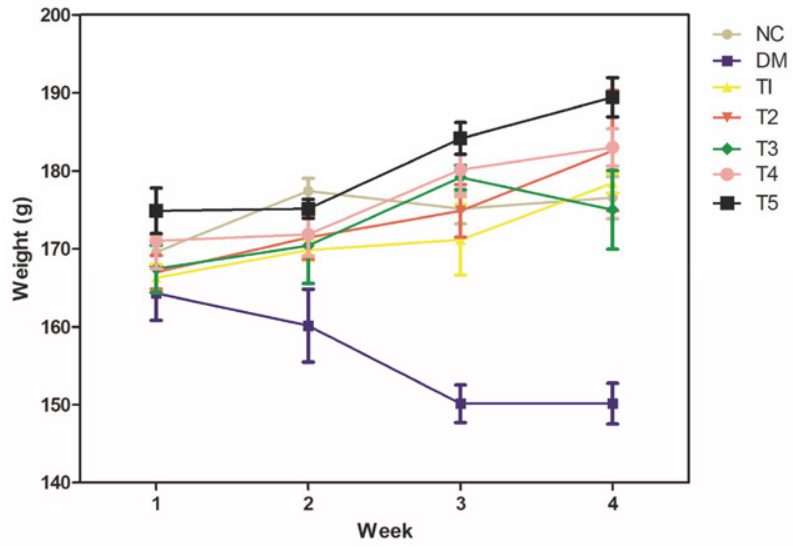

Fig. 1. Effect of treatment on Total Body Weight of Rats. NC - normal control group, DM - diabetic control group, T1 - E. chlorantha treated group, T2 - Metformin treated group, T3 - E. chlorantha + lisinopril treated group, T4 - Metformin + lisinopril treated group and $\mathrm{T} 5$ - Lisinopril treated group.

Table 4 presents the result of the fasting blood glucose level. Fructose -STZ administration exhibited a significant increase in fasting blood glucose $(235.80 \pm 18.94 \mathrm{mg} /$ $\mathrm{dl})$ as compared to the normal control group $(95.12 \pm 0.45$ $\mathrm{mg} / \mathrm{dl}$ ). Before the commencement of treatment (Day 0), the blood glucose levels of all the treatment groups were not different from that of the diabetic non treated group.
On day 5, the fasting blood glucose of the E. chlorantha treated rat $(183.6 \pm 9.31 \mathrm{mg} / \mathrm{dl})$ was observed to be significantly lower than that of the diabetic untreated group $(299.20 \pm 6.46 \mathrm{mg} / \mathrm{dl})$. Similar results were obtained in the rats co -treated with E. chlorantha and lisinopril and the group treated with lisinopril only. At day 15, the blood glucose levels of all the treatment groups were observed not to be significantly different from each other but were significantly lower than that of the diabetic untreated group. They were also observed to be significantly higher than that of the normal control group $(96.53 \pm 0.73 \mathrm{mg} / \mathrm{dl})$.

The results also showed that the highest percentage reduction in blood glucose after $15^{\text {th }}$ day of treatment relative to day 0 was observed in the group co-treated with metformin and lisinopril (60.64\%). This was followed by the group co-treated with the E. chlorantha and lisinopril $(52.70 \%)$. The percentage glucose reduction of the group treated with $E$. chlorantha alone was 47.24 . There was no reduction in the glucose level of the normal and diabetic control groups.

Table 5 shows the inhibitory potential of E. chlorantha extract on the specific activities of $\alpha$-amylase and alpha-glycosidase. The result revealed a dose-related inhibitory effect. The alpha-amylase $\mathrm{IC}_{50}$ values for $E$. chlorantha extract and acarbose were 90 and $65 \mathrm{mg} / \mathrm{ml}$, respectively. The Table also showed an alpha-glucosidase $\mathrm{IC}_{50}$ of 145 and $125 \mathrm{mg} / \mathrm{ml}$ for the extract and acarbose respectively

Table 4. Effect of treatments on fasting blood glucose levels

\begin{tabular}{|c|c|c|c|c|c|c|}
\hline \multirow[b]{2}{*}{ Group } & \multirow[b]{2}{*}{ Treatment } & \multicolumn{4}{|c|}{ Fasting Blood glucose level (mg/dl) } & \multirow[b]{2}{*}{$\begin{array}{c}\text { Total \% } \\
\text { reduction }\end{array}$} \\
\hline & & Day 0 & Day 5 & Day10 & Day 15 & \\
\hline Control & Distilled water & $95.12 \pm 0.45^{\mathrm{a}}$ & $95.56 \pm 0.56^{\mathrm{a}}$ & $95.08 \pm 0.62^{\mathrm{a}}$ & $96.53 \pm 0.73^{\mathrm{a}}$ & - \\
\hline $\begin{array}{l}\text { Diabetic } \\
\text { control }\end{array}$ & $\begin{array}{l}\text { STZ-fructose }+ \text { distilled } \\
\text { water }\end{array}$ & $294.00 \pm 2.31^{b}$ & $299.20 \pm 6.46^{\mathrm{b}}$ & $300.80 \pm 6.67^{b}$ & $301.60 \pm 6.93^{\mathrm{b}}$ & - \\
\hline $\mathrm{T} 1$ & Extract & $235.80 \pm 18.94^{\mathrm{b}}$ & $183.6 \pm 9.31^{\mathrm{c}}$ & $135.80 \pm 5.60^{c}$ & $124.40 \pm 2.35^{\mathrm{c}}$ & $47.24 \%$ \\
\hline $\mathrm{T} 2$ & Metformin & $305.40 \pm 21.55^{\mathrm{b}}$ & $287.60 \pm 2.54^{\mathrm{b}}$ & $207.00 \pm 8.25^{\mathrm{d}}$ & $152.80 \pm 5.83^{c}$ & $50.09 \%$ \\
\hline $\mathrm{T} 3$ & Extract + Lisinopril & $272.80 \pm 11.56^{\mathrm{b}}$ & $200.60 \pm 3.26^{c}$ & $151.40 \pm 6.12^{\mathrm{c}}$ & $129.60 \pm 2.08^{c}$ & $52.70 \%$ \\
\hline $\mathrm{T} 4$ & Metformin + lisinopril & $271.80 \pm 18.33^{\mathrm{b}}$ & $268.60 \pm 9.60^{\mathrm{b}}$ & $182.60 \pm 6.14^{\mathrm{d}}$ & $146.80 \pm 8.09^{c}$ & $60.64 \%$ \\
\hline T5 & Lisinopril only & $248.33 \pm 14.52^{\mathrm{b}}$ & $199.83 \pm 9.06^{c}$ & $171.00 \pm 4.80^{\mathrm{d}}$ & $151.00 \pm 7.55^{\mathrm{c}}$ & $39.10 \%$ \\
\hline
\end{tabular}

Data are presented as mean \pm SEM of 7 determinations. Values in the same column with the same superscripts are not significantly $(P>0.05)$ different from each other.

Table 5. Inhibitory potential of E. chlorantha ethanolic extract on the activity of $\alpha$ amylase and $\alpha$ glucosidase $(n=3$, mean $\pm S D)$.

\begin{tabular}{|c|c|c|c|c|}
\hline \multirow{3}{*}{$\begin{array}{l}\text { Concentrations } \\
(\mathrm{mg} / \mathrm{ml})\end{array}$} & \multicolumn{4}{|c|}{ \% Inhibition } \\
\hline & \multicolumn{2}{|c|}{$\alpha$-Amylase } & \multicolumn{2}{|c|}{ a-Glucosidase } \\
\hline & Acarbose & E. chlorantha & Acarbose & E. chlorantha \\
\hline 50 & $32.87 \pm 3.00$ & $44.52 \pm 5.41$ & $20.72 \pm 0.18$ & $18.67 \pm 0.06$ \\
\hline 100 & $54.11 \pm \mathbf{4 . 0 1}$ & $60.89 \pm 0.24$ & $31.32 \pm 0.25$ & $34.96 \pm 1.01$ \\
\hline 150 & $62.35 \pm 2.91$ & $74.22 \pm 2.13^{\star}$ & $54.70 \pm 4.13$ & $64.96 \pm 3.09$ \\
\hline 200 & $67.21 \pm \mathbf{0 . 7 9}$ & $84.44 \pm 2.14^{\star}$ & $73.42 \pm 0.13$ & $87.93 \pm 2.04^{*}$ \\
\hline $\mathrm{IC}_{50}$ & 65.00 & $90.00^{*}$ & 125.00 & $145.00^{*}$ \\
\hline
\end{tabular}




\section{4. Effect of Treatment on Serum Lipid Profile}

The effect of treatments on serum lipid profile (Table 6) showed a significant increase in serum total cholesterol, total glycerides and LDL-C level and a decrease in the serum HDL-C level in the diabetic group when compared with the control group. Treatment with the extract restored the serum lipid levels. The serum levels of the lipids obtained in the rats treated with the extract alone were not significantly different from those of the diabetic rats treated with metformin but were different from diabetic rats treated with the metformin and lisinopril and the rats co-treated with the extract and lisinopril. The Table also showed that the concentration obtained in the diabetic rats treated with lisinopril alone was different from that of the control group and that of the diabetic control group.

\section{5. Discussion}

The currently available drugs for management of diabetes mellitus have certain drawbacks and therefore, there is a need to find safer and more effective antidiabetic drugs. Result from this study indicates that E. chlorantha stem bark extract is efficacious as an antidiabetic agent in rats and that the efficacy of the extract was not significantly altered when E. chlorantha was co-administered with lisinopril suggesting that combined administration of the plant with lisinopril does not increase its therapeutic indications.

Medicinal plants received much attention due to presence of important bioactive secondary metabolites such as phenolics. ${ }^{36}$ Result of our phytochemical screening showed that $E$. chlorantha stem bark consist of a large proportion of phytochemicals which may play a role as antidiabetic. We reported in this study, that the bioactive compounds contained in the stem bark of the plant belong to the group of alkaloids, saponins, flavonoids, coumarins, anthocyanin and phenolics. The flavonoids were detected to be of highest concentration. Similar studies have also reported the presence of saponins, flavonoids, alkaloids and phenols in aqueous extract of E. chlorantha. ${ }^{37}$ However, it was reported that alkaloids had the highest content
(46.26\%). ${ }^{37}$ These phytochemicals could act in a number of potential mechanisms to show their antidiabetic activities. Some of the potential mechanisms include increase in insulin secretion and action, decreases in hepatic glucose output, regulation of certain enzymes involved in carbohydrate metabolism i.e. $\alpha$-amylase and $\alpha$-glucosidase, modulation of certain regulation molecules such as PPAR $\gamma$ (Peroxisome Proliferator Activated Receptor- $\gamma$ ), hypolipidemic activities, antioxidant effects, enhancement of the expression of glucose transporters etc. ${ }^{38,39,40}$

Both flavonoids and alkaloids had been widely implicated in antidiabetic properties of plants. It was noted that some alkaloids e.g. nuciferine promotes glucose stimulated insulin secretion in rats' pancreatic islets, probably via a pathway involving hepatic nuclear factor $4 \alpha$ or by closing potassium-adenosine triphosphate channels. ${ }^{41}$ Some alkaloids (i.e. mescaline, pyrrole, pyridine, tropane, aporphine, and quercetin) have been reported to have antioxidant and antimicrobial properties. ${ }^{42,43}$ Studies on the antidiabetic potential of flavonoids from plants showed that flavonoids regenerate pancreatic islets and increase insulin secretion in streptozotocin (STZ)-induced diabetic rats. ${ }^{44}$ It also stimulates insulin release and enhance glucose uptake from isolated islet cells. ${ }^{45}$

Streptozotocin (STZ)-fructose type 2 diabetes model shares a number of features with human type 2 diabetes mellitus (TDM2) both histologically and metabolically and is characterized by moderate stable hyperglycemia. ${ }^{46,47}$ This is why in this study, STZ-fructose induced diabetes model was used. Streptozotocin injection caused $\beta$ cells degeneration in rats, resulting in decrease in the release of insulin by the pancreas. Furthermore, high fructose ingestion causes insulin resistance (IR). This contributes negatively to blood glucose homeostasis thereby inducing hyperinsulinemia which predispose to type 2 diabetes. Result of fasting blood glucose of $\geq 200 \mathrm{mg} / \mathrm{dl}$ obtained in this study following STZ-fructose administration confirms induction of type 2 diabetes. This is similar to report from previous findings. ${ }^{48,49,50}$

Our study also showed that changes in body weight of fructose-streptozotocin-induced diabetes is associated with characteristic loss of body weight. This we hypothesized may due to increased muscle wasting and possibly

Table 6. Effect of treatments on serum lipid profiles

\begin{tabular}{lcccrc}
\hline Group & Treatment & LDL-C $(\mathbf{m g} / \mathbf{d l})$ & HDL-C $(\mathbf{m g} / \mathbf{d l})$ & TG $(\mathbf{m g} / \mathbf{d l})$ & TC $(\mathbf{m g} / \mathbf{d l})$ \\
\hline Control & Distilled water & $1.26 \pm 0.02^{\mathrm{a}}$ & $1.26 \pm 0.82^{\mathrm{b}}$ & $0.78 \pm 0.82^{\mathrm{a}}$ & $0.87 \pm 0.97^{\mathrm{a}}$ \\
Model & STZ-fructose + distilled water & $6.09 \pm 0.95^{\mathrm{c}}$ & $0.56 \pm 0.07^{\mathrm{a}}$ & $1.50 \pm 0.47^{\mathrm{b}}$ & $1.66 \pm 0.48^{\mathrm{b}}$ \\
T1 & Extract & $2.08 \pm 0.41^{\mathrm{ab}}$ & $0.97 \pm 0.40^{\mathrm{b}}$ & $0.89 \pm 0.50^{\mathrm{a}}$ & $0.98 \pm 0.09^{\mathrm{a}}$ \\
T2 & Metformin & $2.83 \pm 0.06^{\mathrm{ab}}$ & $1.10 \pm 0.63^{\mathrm{b}}$ & $0.93 \pm 0.29^{\mathrm{a}}$ & $1.06 \pm 0.79^{\mathrm{a}}$ \\
T3 & Extract + Lisinopril & $1.73 \pm 1.00^{\mathrm{ab}}$ & $1.07 \pm 0.55^{\mathrm{b}}$ & $0.77 \pm 0.93^{\mathrm{a}}$ & $0.85 \pm 0.16^{\mathrm{a}}$ \\
T4 & Metformin + lisinopril & $2.36 \pm 0.71^{\mathrm{ab}}$ & $1.18 \pm 0.70^{\mathrm{b}}$ & $0.81 \pm 0.03^{\mathrm{a}}$ & $0.96 \pm 0.30^{\mathrm{a}}$ \\
T5 & Lisinopril only & $3.08 \pm 0.56^{\mathrm{b}}$ & $0.97 \pm 0.17^{\mathrm{b}}$ & $1.07 \pm 0.20^{\mathrm{a}}$ & $1.08 \pm 0.91^{\mathrm{a}}$ \\
\hline
\end{tabular}

Data are presented as mean \pm SEM of 7 determinations. Values in the same column with the same superscripts are not significantly different $(p>$ $0.05)$ from each other. 
loss of tissue proteins which is similar to the previous observations. ${ }^{50,51}$ As expected in the diabetic control group, the body weight of rats was progressively reduced whereas, in all the E. chlorantha treated rats and those co-administered with lisinopril there was a progressive improvement in the body weight. This indicates that treatment prevented muscle tissue damage associated with hyperglycemic condition.

In the management of diabetes mellitus, alpha-glucosidase and alpha-amylase enzymes represent the most crucial of the pharmacological targets. ${ }^{52,53}$ These enzymes facilitate hydrolysis of starch to glucose with consequential increase in the systemic concentration of glucose. Hence, the inhibition of these enzymes activities delays glucose absorption and moderates postprandial blood sugar level..$^{53}$ In this study, the in vitro alpha-amylase inhibitory activities of the ethanol extract of $E$. chlorantha were investigated. The extract (50-200 mg/ml) exhibited potent $a$-amylase inhibitory activity in a dose dependent manner. This was similar to what was obtained with acarbose. The $\mathrm{IC}_{50}$ obtained with acarbose was lower than that of E. chlorantha extract. Furthermore, the alpha-glycosidase inhibitory assay of the ethanolic extract of $E$. chlorantha stem bark revealed a significant inhibitory action of alpha-glucosidase enzyme. The percentage inhibition at $50-200 \mathrm{mg} / \mathrm{ml} \mathrm{con-}$ centrations of $E$. chlorantha extract also showed a dose dependent increase with an $\mathrm{IC}_{50}$ of $145 \mathrm{mg} / \mathrm{ml}$. Similarly, acarbose showed alpha-glucosidase inhibitory activity with an $\mathrm{IC}_{50}$ value of $125 \mathrm{mg} / \mathrm{ml}$. The result indicates that the ethanolic extract of $E$. chlorantha is a potent alpha-amylase and alpha-glucosidase inhibitor similar to acarbose. Previous reports had noted that alpha-amylase and alpha-glucosidase are the main pharmacological targets in the management of diabetes. ${ }^{52}$ These enzymes facilitate hydrolysis of starch to glucose with consequential increase in the systemic concentration of glucose in diabetes. This increased hyperglycemia may constitute a significant risk factor for diabetic complications. Our study suggests that E. chlorantha stem bark may be used as starch blockers indicating that the plant may prevent or slow the absorption of starch in to the body mainly by blocking the hydrolysis of 1,4-glycosidic linkages of starch and other oligosaccharides into maltose, maltriose and other simple sugars. Administration of E. chlorantha stem bark extract to diabetic rats caused significant reduction of blood glucose level compared to the control and diabetic untreated group.

Many previous studies have provided evidence that oxidative stress resulting from increased reactive oxygen species (ROS) is a key factor in the pathogenesis of diabetes. ${ }^{53,54}$ Our study showed that E. chlorantha elicited marked antioxidant potentials suggesting that the plant has the capacity to regulate or stall free radicals chain reactions associated with diabetes complications, which is in agreement with previous report. ${ }^{53}$ Natural products are the major source of antioxidants which delay the development of diabetes. ${ }^{40}$
The role of dyslipidemia in the development of diabetes macrovascular complications has been reported. ${ }^{1,4}$ In this study, the STZ-fructose model of type 2 diabetes exhibited abnormalities in lipid metabolism as evidenced by the significant elevation of serum TC, TG, LDL-C and reduction of HDL-C levels. A previous study reported that treatment with metformin significantly reduced the TC, TG, LDL-C level and increased HDL-C levels in diabetic rats. ${ }^{55}$ The extract was shown to improve the condition of diabetic mellitus as indicated by the lipid profile monitored in the study, thus showing its good antidiabetic activity in STZ-fructose-induced hyperglycemic rats. Lisinopril, an angiotensin converting enzyme inhibitor (ACE-I) acts by preventing the formation of Ang II, which has also been implicated in insulin resistance by inhibiting insulin receptor dependent PI3K signaling. ${ }^{56}$ Therefore, the blockade of this substance is important in affecting insulin sensitivity. The co-administration of lisinopril and the extract did not show any difference from that achieved with the extract alone. Serum total cholesterol, LDL cholesterol and triglycerides decreased in all the treated groups when compared with the model group. No significant difference was however observed in all these parameters when compared among the treatment groups. Serum HDL cholesterol was also observed to increase in all treatment groups compared with the model group, but no difference was observed when compared among the treatment groups. In previous study, inhibitors of the renin angiotensin system, such as angiotensin converting enzyme (ACE) inhibitors was reported to ameliorate the lipid abnormalities to a substantial extent. ${ }^{57}$

\section{Conclusion}

The use of $E$. chlorantha in the management of diabetes is a common practice among some local communities in Nigeria. Data obtained from this study indicates that $E$. chlorantha is efficacious as antidiabetic agent and that combined administration of $E$. chlorantha and lisinopril does not in any way influence the efficacy of $E$. chlorantha stem bark as an antidiabetic agent. The study identified phytoconstituents belonging to the phenolics, flavonoids, saponins and alkaloids as some of the bioactive compounds which may be responsible for this pharmacological property. Study has just been concluded in our laboratory to evaluate the toxicological implication of the combined administration of these agents. ${ }^{58}$
Abbreviations
HDL-C: High-Density Lipoprotein Cholesterol
LDL-C: Low-Density Lipoprotein Cholesterol
ACE: Angiotensin converting enzyme
HDI: Herb-Drug interactions
DPPH: 1,1-diphenyl-2-picryl-hydrazyl 
TDM2: Human type 2 diabetes mellitus

ROS: $\quad$ Reactive Oxygen Species

PPAR $\gamma$ : Peroxisome Proliferator Activated Receptor- $\gamma$

\section{References}

1. G. Keerthana, M. K. Kalaivani, A. Sumathy, Asian J. Pharm. Clin. Res., 2013, 6, 32-36.

2. G. H. Tomkin, Diabetes Care, 2008, 31, S241-S248. DOI: $10.2337 / \mathrm{dc} 08$-s 260

3. B. A. Salau, O. Osilesi, G. O. Idowu, S. Musa, E. O. Ajani, Afr. J. Med. Pharm. Sci., 2003, 7, 6-11.

4. L. A. Leiter, J. Genest, S. B. Harris, G. Lewis, Can. J. Diabetes., 2006, 30, 230-240. DOI:10.2337/diacare.21.1.160

5. J. Thrasher, Am. J. Med., 2017, 130, S4-S17.

DOI:10.1016/j.amjmed.2017.04.004

6. A. Rawshani, A. Rawshani, S. Franzen, N. Sattar, B. Eliasson, A. M. Svensson, B. Zethelius, M. Miftaraj, D. K. McGuire, A. Rosengren, S. Gudbjornsdottir, N. Engl. J. Med., 2018, 379, 633-644. DOI:10.1056/NEJMoa1800256

7. American Diabetes Association, Diabetes Care, 2018, 41, S13S27. DOI: $10.2337 / \mathrm{dc} 18-\mathrm{S} 002$

8. M. J. Davies, D. A. D’Alessio, J. Fradkin, W. N. Kernan, C. Mathieu, G. Mingrone, P. Rossing, A. Tsapas, D. J. Wexler, J. B. Buse, Diabetes Care, 2018, 41, 2669-2701.

DOI:10.2337/dci18-0033

9. American Diabetes Association, Diabetes Care, 2019, 42: S90S102. DOI:10.2337/dc19-S009

10. V. Nivetha, V. Subramaniyan, G. Manikandan, M. Divya Bharathi, T. Krishna Prasanth, K. Manjula, J. Pharmacogn. Phytochem., 2019, 8, 1060-1064.

11. M.S. Hashim, V. Lincy, V. Remya, M. Teena, L. Anila, Food Chem., 2005, 92, 653-660.

DOI:10.1016/j.foodchem.2004.08.027

12. A. B. Medagama, R. Bandara, Nutr. J., 2014, 13, 102. DOI:10.1186/1475-2891-13-102

13. H. Choudhury, M. Pandey, C. K. Hua, C. S. Mun, J. K. Jing, L. Kong, L. Y. Ern, N. A. Ashraf, S. W. Kit, T. S. Yee, M. R. Pichika. J. Tradit. Complement. Med., 2018, 8, 361-376. DOI:10.1016/j.jtcme.2017.08.012

14. A. A. Adesokan, M. T. Yakubu, B. V. Owoyele, M. A. Akanji, A. O. Soladoye, O. K. Lawal, Afr. J. Biochem. Res., 2008, 2, 65-169. DOI:10.5897/AJBR2008.

15. N. Tsabang, P. V. Fokou, L. R. Tchokouaha, B. Noguem, I. Bakarnga-Via, M. S. Nguepi, B.A. Nkongmeneck, F. F. Boyom, J. Ethnopharmacol., 2012, 139, 171-180.

DOI:10.1016/j.jep.2011.10.035

16. O. E. Adebiyi, M. O. Abatan, Interdiscip Toxicol., 2013, 6, 145-151. DOI:10.2478/intox-2013-0023

17. M. N Djimeli, J. M. N. Mendimi, S. P. C. Fodouop, C. Fokunang, S. S. Atsafack, O. Dogmo, M. Guewo-Fokeng, D. Gatsing, Am. J. Pharmacol. Ther., 2017, 1, 020-027.

18. R. M. E. Etame, R. S. Mouokeu, F. S. M. Poundeu, I. K. Voukeng, C. L. P. Cidjeu, A. T. Tiabou, A. J. G. Yaya, R. A. N.
Ngane, J. R. Kuiate, F. X. Etoa, BMC Complement Altern Med., 2019, 19, 56. DOI:10.1186/s12906-019-2459-y

19. J. Coyle, S. Gardner, C. M. White, Ann. Pharmacother. 2004, 38, 1731-1738. DOI:10.1345/aph.1E182

20. M. de Lima, S. Toccafondo, S. M. Vieira, Planta Medica, 2004, 78, 1400-1415. DOI:10.1055/s-0032-1315145

21. O. O. Odebiyi, E. A. Sofowora, IIoydia, 1978, 41, 234-246.

22. J. H. Brunner, Anal. Chem., 1984, 34, 1314-1326.

DOI:10.1007/BF02844409

23. T. Swain, Herbivores: Their Interaction with Secondary Plant Metabolites, Academic Press, London, 1979, pp. 657-682.

24. M. Plummer, D. T. Plummer, in Introduction to Practical Biochemistry, Tata McGraw Hill Publishing Company Limited, India, 2001.

25. B. I. Faridha, R. Mohankumar, M. Jeevan, K. Ramani, Indian J. Microbiol., 2016, 56, 426-432.

DOI:10.1007/s12088-016-0609-1

26. A. Turkoglu, M. E. Duru, N. Mercan, I. Kivrak, K. Gezer, Food Chem., 2007, 101, 267-273.

DOI:10.1016/j.foodchem.2006.01.025

27. R. J. Ruch, S. J. Cheng, J. E. Klaunig, Carcinogenesis, 1989, 10, 1003. DOI:10.1093/carcin/10.6.1003

28. N. Smirnoff, Q. J. Cumbes, Phytochem., 1989, 28, 1057-1060. DOI:10.1016/0031-9422(89)80182-7

29. C. C. Yen, P. D. Duh, J. Am. Oil Chem. Soc., 1993, 70, 383-386. DOI:10.1007/BF02552711

30. G. Oboh, A. J. Akinyemi, A. O. Ademiluyi, A.S. Adefegha, J. Food Nutr. Res., 2010, 49, 14-20.

31. E. Apostolidis, Y. I. Kwon, K. Shetty, Innov. Food Sci. Emerg. Technol., 2007, 8, 46-54.

DOI:10.1016/j.ifset.2006.06.001

32. R. D. Wilson, M. S. Islam, Pharmacol. Rep., 2012, 64, 129-139. DOI:10.1016/S1734-1140(12)70739-9

33. T. M. M. Kuissu, E. G. Enow-Orock, C. Mezui, Z. E. Nkwengoua, V.P. Tan, B. Nyasse, Br. J. Pharm. Res., 2015, 8, 1-13. DOI $: 10.9734 / B J P R / 2015 / 19035$.

34. T. T. Olivier, N. T. Francis, J. S. Armel, Edorium J. Med., 2016, 3, 12-18.

35. National Research Council, Guide for the Care and Use of Laboratory Animals, National Academic Press, Washington, 2011, pp. 37-103.

36. E. O. Ajani, S. Sabiu, M. Zakari, N. Olanipekun, J. K. Akintunde, F. A. Bamisaye, J. Biol. Active Prod., 2017, 7, 166-170. DOI:10.1080/22311866.2017.1329667

37. A. A. Adesokan, M. A. Akanji, M. T. Yakubu, Afr. J. Biotechnol., 2007, 6, 2502-2505.

38. O. Elekofehinti, J. P. Kamdem, I. J. Kade, J. B. T. Rocha, I. G. Adanlawo, S. Afr. J. Bot., 2013, 88, 56-61.

DOI:10.1016/j.sajb.2013.04.010

39. D. Y. Kwon, Y. S. Kim, S. Y. Ryu, M. R. Cha, G. H. Yon, H. J. Yang, M. J. Kim, S. Kang, S. Park, Eur. J. Nutr., 2012, 51, 529-540. DOI:10.1007/s00394-011-0236-x

40. C. N. Kunyanga, J. K. Imungi, M. Okoth, C. Momanyi, H. K. Biesalski, V. Vadivel, J. Food Sci., 2011, 76, 560-567. DOI:10.1111/j.1750-3841.2011.02116.X

41. Z. Q. Wang, F. E. Lu, S. H. Leng, X. S. Fang, G. Chen, Z. S. 
Wang, L. P. Dong, Z. Q. Yan, World J. Gastroenterol., 2008, 4, 6004-11. DOI:10.3748/wjg.14.6004

42. K. Akter, E. C. Barnes, J. J Brophy, D. Harrington, Y. Community Elders, S.R. Vemulpad, J. F. Jamie, Evid. Based Complement. Alternat. Med., 2016, 2016, 4683059.

DOI:10.1155/2016/4683059

43. L. Othman, A. Sleiman, R. M. Abdel-Massih, Front. Microbiol., 2019 10, 911. DOI:10.3389/fmicb.2019.00911

44. M. Vessal, M. Hemmati, M. Vasei, Comp. Biochem. Physiol., 2003, 135, 357-364.

DOI:10.1016/S1532-0456(03)00140-6

45. R. Singh, A. Tasleem, K. Imran, S. Poonam, J. Biomed. Ther. Sci., 2014, 1, 1-33. DOI:10.1155/2014/741785

46. R. D. Wilson, M. S. Islam, Pharmacol. Rep., 2012, 64, 129-139. DOI:10.1016/S1734-1140(12)70739-9

47. R. K. Suman, I. Ray Mohanty, M. K. Borde, U. Maheshwari, Y. A. Deshmukh, Adv. Pharmacol. Sci., 2016, 9463476. DOI:10.1155/2016/9463476

48. G. J. Litherland, E. Hajduch, G. W. Gould, H.S. Hundal, Mol. Cell Biochem., 2004, 261, 23-33.

DOI:10.1023/B:MCBI.0000028734.77867.d2
49. R. D. Wilson, M. S. Islam, Acta Pol. Pharm., 2015, 72, 153-160

50. K. Chandan, K. Raj, N. Shamshun, Int. J. Pharm. Res. Allied Sci., 2014, 3, 195-202.

51. D. Cheng, B. Liang, Y. Li. Biomed. Res. Int., 2013, 2013, 162724. DOI:10.1155/2013/162724

52. A. J. Krentz, C. J. Bailey, Drugs. 2005, 65, 385-411. DOI:10.2165/00003495-200565030-00005

53. S. Sabiu, A. O. T. Ashafa, S. Afr. J. Bot., 2016, 105, 264-269. DOI:10.1016/j.sajb.2016.04.007

54. T. J. Makhafola, E. E. Elgorashi, L. J. McGaw, M. D. Awouafack, L. Verschaeve, J. N. Eloff, BMC Compliment. Altern. Med., 2017, 17, 446. DOI:10.1186/s12906-017-1935-5

55. T. A. Ismail, M. M. Soliman, M. A. Nassan, Exp. Ther. Med., 2015, 9, 1921-1930. DOI:10.3892/etm.2015.2354

56. A. Ribeiro-Oliveira, A. I. Nogueira, R. M. Pereira, W. W. Boas, R. A. Dos Santos, A. C. Simoes, Vasc. Health Risk Manag., 2008, 4, 787-803. DOI:10.2147/VHRM.S1905

57. T. Keilani, W. A. Schlueter, D. C. Levin, Ann. Intern. Med., 1983, 118, 246-254.

DOI:10.7326/0003-4819-118-4-199302150-00002

58. E. O. Ajani, L. B. Ibrahim. Clin. Phytosci., 2020, 6, DOI:10.1186/s40816-020-00174-Z

\section{Povzetek}

Ta študija potrjuje protidiabetično učinkovanje lubja Enantia chlorantha in morebitne terapevtske posledice sočasne uporabe lizinoprila in E. chlorantha pri podganah s sladkorno boleznijo tipa 2. Lubje E. chlorantha je bilo ekstrahirano $\mathrm{s}$ hladno maceracijo. Inhibitorni učinek rastline na encime, ki presnavljajo ogljikove hidrate, in njene antioksidativne potenciale so bili ovrednoteni in vitro. Ekstrakt je izkazoval inhibitorno delovanje na $\alpha$-amilazo in $\alpha$-glukozidazo ter antioksidativne lastnosti in vitro. Aplikacija ekstrakta in vivo je normalizirala hiperglikemijo na tešče, tako da je znižala raven glukoze v krvi v primerjavi z nezdravljenimi diabetičnimi podganami za 47,24 \%. Sočasna uporaba E. chlorantha in lizinoprila je normalizirala nivo glukoze v serumu in nivo serumskega lipidnega profila. Lubje E. chlorantha je pokazalo antidiabetični potencial v primerjavi s standardnim antidiabetikom (metformin). Študija je pokazala tudi, da je rastlina vsebovala nekatere bioaktivne spojine, za katere domnevamo, da bi lahko bile odgovorne za opažene učinke. Sočasna uporaba rastline $\mathrm{z}$ lizinoprilom ni prinesla pomembnega terapevtskega izboljšanja ravni glukoze $\mathrm{v}$ serumu in lipidnega profila.

Except when otherwise noted, articles in this journal are published under the terms and conditions of the Creative Commons Attribution 4.0 International License 